IZA DP No. 4930

Joblessness and Perceptions about the Effectiveness of Democracy

Duha Altindag

Naci Mocan

May 2010 


\title{
Joblessness and Perceptions about the Effectiveness of Democracy
}

\author{
Duha Altindag \\ Louisiana State University \\ Naci Mocan \\ Louisiana State University, \\ NBER and IZA
}

Discussion Paper No. 4930

May 2010

IZA

P.O. Box 7240

53072 Bonn

Germany

Phone: +49-228-3894-0

Fax: +49-228-3894-180

E-mail: iza@iza.org

\begin{abstract}
Any opinions expressed here are those of the author(s) and not those of IZA. Research published in this series may include views on policy, but the institute itself takes no institutional policy positions.

The Institute for the Study of Labor (IZA) in Bonn is a local and virtual international research center and a place of communication between science, politics and business. IZA is an independent nonprofit organization supported by Deutsche Post Foundation. The center is associated with the University of Bonn and offers a stimulating research environment through its international network, workshops and conferences, data service, project support, research visits and doctoral program. IZA engages in (i) original and internationally competitive research in all fields of labor economics, (ii) development of policy concepts, and (iii) dissemination of research results and concepts to the interested public.
\end{abstract}

IZA Discussion Papers often represent preliminary work and are circulated to encourage discussion. Citation of such a paper should account for its provisional character. A revised version may be available directly from the author. 
IZA Discussion Paper No. 4930

May 2010

\section{ABSTRACT \\ Joblessness and Perceptions about the Effectiveness of Democracy*}

Using micro data on more than 130,000 individuals from 69 countries, we analyze the extent to which joblessness of the individuals and the prevailing unemployment rate in the country impact perceptions of the effectiveness of democracy. We find that personal joblessness experience translates into negative opinions about the effectiveness of democracy and it increases the desire for a rouge leader. Evidence from people who live in European countries suggests that being jobless for more than a year is the source of discontent. We also find that well-educated and wealthier individuals are less likely to indicate that democracies are ineffective, regardless of joblessness. People's beliefs about the effectiveness of democracy as system of governance are also shaped by the unemployment rate in countries with low levels of democracy. The results suggest that periods of high unemployment and joblessness could hinder the development of democracy or threaten its existence.

JEL Classification: J2, O1, P1

Keywords: $\quad$ unemployment duration, democracy, education, development, World Values Survey

Corresponding author:

Naci Mocan

Department of Economics

Louisiana State University

2119 Taylor Hall

Baton Rouge, LA 70803-6306

USA

E-mail: mocan@Isu.edu

\footnotetext{
* We thank Robert Newman for helpful comments and Elif Filiz for research assistance.
} 


\section{Introduction}

Economists are increasingly interested in the impact of institutions on economic development. Rigobon and Rodrik (2005), Dollar and Kraay (2003) and Acemoglu and Robinson (2000) argue that high quality institutions in a country, represented by a number of dimensions such as the protection of property rights and a functioning democracy, foster economic development because they promote investment in human capital and physical capital. Countries that are governed by high quality institutions experience higher capital accumulation, productivity, and output per worker (Hall and Jones 1999). Rodrik (1999) shows that the extent of democracy in a country has a positive impact on wages received by manufacturing workers. Barro (1996) argues that a more democratic regime stimulates economic growth when the level of political freedom is low. ${ }^{1}$

The potential impact of economic development on the extent of democracy is an equally important research question, and whether an increase in income of a country causes its democracy to improve has been a subject of recent debate. As widely quoted in this literature, a common perspective, articulated by Lipset (1959) is that "From Aristotle down to the present, men have argued that only in a wealthy society in which relatively few citizens lived in real poverty could a situation exist in which the mass of the population could intelligently participate in politics an could develop the self-restraint necessary to

\footnotetext{
${ }^{1}$ In the same paper Barro identifies a nonlinear impact of democracy; i.e. democracy hinders growth when a moderate level of democracy has already been attained. He argues that this could because democracy may encourage redistribution of income from the rich to the poor and may enhance the power of interest groups. It has also been suggested that institutions have no direct impact on economic growth. Rather, human capital is the main driver of economic growth and good economic policies, sometimes implemented by dictators, can generate high economic growth.
} 
avoid succumbing to the appeals of irresponsible demagogues.” Barro (1999) finds that the propensity for democracy rises with per capita GDP. Minier (2001) shows that an increase in per capita GDP is associated with an enhanced demand for democracy, approximated by pro-democracy public demonstrations. Papaioannou and Siourounis (2008) report that economic development is a key factor determining the intensity of democratic reforms in a country. On the other hand, Acemoglu et al. (2008) find no significant impact of GDP growth on democratization.

This paper aims to contribute to the literature on the determinants of democracy. However, it differs from the previous work in an important way. It employs individuallevel, rather than country-level data. The paper investigates the extent to which an individual's own joblessness and the unemployment rate of his/her country make him/her more likely to reveal a distaste towards the effectiveness of democracy. Acemoglu and Robinson (2001) argue that regime changes are more likely during recessionary periods; and Haggard and Kaufman (1995) point out that many Latin American transitions to democracy coincided with economic crises. The implication is that short-term economic downturns may prompt reactions towards the existing regime. While it is sensible to think that undesirable economic conditions would trigger enhanced opposition movements against existing undemocratic regimes, it is equally reasonable to argue that tough economic conditions in a democratic regime could prompt negative feelings towards democracy. For example, Gasiorowski (1995) and Prezworski et al. (1996) demonstrate that recessions significantly increase the probability of a coup. Because of the free-rider problem, a change in perceptions about the effectiveness of democracy among the residents of a country does not necessarily imply involvement in direct actions against democracy, such as participation 
in a revolt (MacCulloch 2005). Nevertheless, it is important to understand how perceptions about democracy are impacted by personal economic conditions as these perceptions may translate into political actions against democracy in subtle ways such as voting for a political party which has an explicit or implicit anti-democratic platform.

We use micro data on 131,615 individuals from 69 countries to investigate the extent to which personal joblessness of individuals and the unemployment rate in their country impact their perceptions of operational efficiency of democracy. We find that observationally identical individuals have weaker beliefs about democratic efficiency if they are jobless and if duration of joblessness is longer than one year. The same is true if the unemployment rate of the country goes up and if these individuals live in countries with low levels of democracy. These results underline the importance of labor market policies in developing countries with struggling democracies. We also find that higher household income and personal education promote stronger perceptions about the effectiveness of democracy. Section II describes the empirical specification and the data. Section III presents the results and Section IV is the conclusion.

\section{Empirical Specification}

The basic model can be specified as follows:

$$
\mathrm{D}_{\mathrm{ict}}{ }^{*}=\alpha_{\mathrm{ict}}+\beta \text { Jobless }_{\mathrm{ict}}+\gamma \mathrm{UR}_{\mathrm{ct}}+\mathrm{X}_{\mathrm{ict}} \boldsymbol{\Omega}^{\prime}+\mathrm{Y}_{\mathrm{ct}} \boldsymbol{\Psi}^{\prime}+\tau_{\mathrm{t}}+\boldsymbol{\varepsilon}_{\mathrm{ict}},
$$

where $\mathrm{D}_{\mathrm{ict}}{ }^{*}$ measures individual $i$ 's propensity for unhappiness with democratic efficiency who lives in country c, who was surveyed in year $t$. Although an individual's 
propensity for negative feelings towards democracy is unobservable, an indicator variable $D_{\text {ict }}$ is observed to be equal to 1 when $D_{\text {ict }} *>0$ so that $\left(D_{\text {ict }}=1\right)=\operatorname{Prob}\left(\alpha_{\mathrm{ict}}+\beta\right.$ Jobless $\left._{\mathrm{ic}}+\gamma \mathrm{UR}_{\mathrm{ct}}+\mathrm{X}_{\mathrm{ict}} \boldsymbol{\Omega}^{\prime}+\mathrm{Y}_{\mathrm{ct}} \boldsymbol{\Psi}^{\prime}+\tau_{\mathrm{t}}+\boldsymbol{\varepsilon}_{\mathrm{ict}}>0\right)$. If the error term $\boldsymbol{\varepsilon}_{\mathrm{ict}}$ in Equation (1) is normally distributed, then the result is a standard single-equation probit specification.

We employ three different variables to represent $\mathrm{D}_{\text {ict }}$ to capture the beliefs about the effectiveness of democracy. The first measure is an indicator of the extent to which the individual believes that the economic system runs badly in democracies. The second one gauges general effectiveness of democracy as a political decision-making system. It measures whether the individual believes that democracies are indecisive and have too much quibbling. The third one measures the preference of the individual towards a leader who does not bother with key aspects of a democracy such as the parliament and elections. The details of these variables are described in the data section below.

The specification depicted by Equation (1) is similar in spirit to a line of research conducted by political scientists and economists to explain the voting patterns and to forecast election results. For example, Kramer (1971), Stigler (1973), Fair (1978) analyzed the impact of economic conditions on the percentage of votes received by incumbent and opposition parties in the U.S. Presidential or Congressional elections. Markus (1988) and Nannestad and Paldam (1997) analyzed the propensity to vote for the incumbent as a function of personal economic circumstances and aggregate macroeconomic conditions in the U.S. and in Denmark, respectively. Garand and Ulrich (2009) investigate the impact of macroeconomic conditions on individuals' subjective evaluations of the state of the economy, and the resultant voting behavior. 
The key explanatory variable Jobless $s_{i c t}$ is a dichotomous indicator that identifies if person $i$ who lives in country $c$ and surveyed in year $t$ is unemployed. We also investigate the extent to which the aggregate unemployment rate in the country (UR) has an impact on people's attitudes towards the efficiency of democracy. The impact of the unemployment rate, holding constant one’s own employment status, may work through at least two different channels. First, regardless of whether a person is employed or unemployed, an increase in the unemployment rate of the country may impact the individual's expected future utility. Specifically, an increase in overall joblessness in the economy may decrease the individual's subjective probability of future employment and therefore it would reduce his/her expected future utility. This could in turn influence his/her propensity for satisfaction with democracy as a system of governance. Second, an increase in the unemployment rate may have a direct impact on individuals' level of happiness if the utility function contains other-regarding preferences. For example, it has been shown that individual happiness declines as the unemployment rate goes up, conditional on personal employment. (Clark and Oswald 1994, Clark 2003, Winkelmann and Winkelmann 1998). Therefore, an increase in the unemployment rate may alter attitudes towards democracy through its direct impact on utility.

Differences across individuals with respect to their general attitudes towards democracy are represented by $\alpha_{i c t}$ in Equation (1), where larger values indicate higher baseline propensity for dissatisfaction with democracy. Note that $\alpha$ has a subscript $c$ indicating that the extent of unhappiness with democracy may vary between countries. This could be because of cultural, historical and institutional differences between countries. Also note that $\alpha$ has subscript $i$, indicating that predisposition to dissatisfaction with democracy 
may vary between people who live in the same country. This could be because of differences in family background and personal characteristics.

It is possible that individuals who have negative attitudes towards democracy (those with large values of $\alpha$ ) face difficulties in finding and retaining jobs. ${ }^{2}$ If $\alpha$ is positively correlated with the propensity for joblessness, the failure to account for it would bias $\beta$ upwards. To guard against this possibility, the model includes the vector X, containing personal attributes of the individual, such as age, gender, type of employment if the person is not jobless (such as having a part-time job, having a full time job, being a student, being a housewife and so on), marital status, the number of children, the level of education and income of the individual. However, inclusion of personal characteristics may not fully control for the unobserved impact of the individual's general attitude towards democracy. Therefore, we add a control variable to the model that gauges the person's general attitude towards democracy as a measure of $\alpha$. This variable is created by the reactions to the question "Democracy may have problems but it is better than any other form of government.” Possible answers to this question are strongly agree, agree, disagree and strongly disagree. The variable Democracy is Not Better takes the value of one if the respondent disagrees or strongly disagrees with the statement about the merit of democracy. We discuss potential empirical issues, and threats to identification in the results section. Specifically, we address potential reverse causality and a potential for a spurious relationship between joblessness and perceptions about democratic efficiency.

${ }^{2}$ This is because the empirical analyses are conducted in a sample of countries, the majority of which is democratic, although the extent of democracy differs between the countries. Examples of undemocratic countries are Morocco, which is governed by a constitutional monarchy and Saudi Arabia, which is an Islamic monarchy. 
In Equation (1) Y stands for a vector of country attributes such as the proportions of Muslims, Catholics and Protestants in the country, an indicator variable to specify if the country was ever colonized, and the Human Development Index of the United Nations Development Program (UNDP). This index includes such elements as life expectancy at birth, the adult literacy rate and GDP per capita. Other country variables include the magnitude of international trade (the share of exports plus imports in total GDP) as a measure of openness, military expenditures as a proportion of GDP, and the inflation rate in the country during the survey year.

III. Data

The primary data are obtained from the two waves of the World Values Survey (WVS). The WVS includes information on individual's beliefs, values and attitudes towards various issues ranging from politics to environmental protection to religion. The data set also includes information on personal characteristics of the respondents. Interviews have been carried out with nationally representative samples (at least 1,000 individuals from each country) of 69 countries (which make up about 85 percent of the world's population) on all six inhabited continents in five waves between 1981 and 2007. We merged the WVS data with various country attributes to obtain our final sample of 131,615 individuals from 67 countries. $^{3}$

Descriptive statistics are provided in Table 1. The three dependent variables are Democracy is Bad for the Economy, Democracies are Indecisive and Rogue Leader. Democracy is Bad for the Economy takes the value of 1 if the respondent agrees or strongly

${ }^{3}$ Data from 67 countries in the $3^{\text {rd }}$ and the $4^{\text {th }}$ waves covering years 1994 to 2004 are analyzed in this paper since the dependent variables are based on the questions that are asked only in these waves. 
agrees with the statement that "In democracies, the economic system runs badly," and zero if the respondent disagrees or strongly disagrees. Democracies are Indecisive takes the value of 1 if the respondent agrees or strongly agrees with the statement that "Democracies are indecisive and have too much quibbling," and zero if he/she disagrees or strongly disagrees. Rogue Leader takes the value of 1 if the respondent indicated that "Having a strong leader who does not have to bother with parliament and elections” is very good or fairly good; and zero it the respondent replied that such a leader is bad or very bad.

Low Income is a dichotomous indicator that takes the value of 1 if the person's household income belongs to the bottom third of the income distribution of his/her country. Medium Income is equal to 1 if the household income is in the middle-third of the income distribution of the country and zero otherwise. High Income identifies whether the personal household income belongs to the top third of the country's income distribution.

Low Education is a dummy variable which indicates that the person has completed at most elementary education, but has not completed a technical or vocational training. If the person has completed secondary school, which includes technical or vocational training or university-preparatory type education, Middle Education takes the value of 1, and it is zero otherwise. The indicator variable High Education is equal to 1 if the individual has a university degree, has attended university, or has received a tertiary certificate.

Family characteristics of the individuals are captured by dummies for marital status and the number of children. Specifically, we categorized individuals into three groups according to their marital status: Single, Married, and Divorced/Widowed, where Divorced/Widowed includes those who are separated. Similarly, five mutually exclusive dummy variables identify the number of children of the person: No Children, 1 Child, 2 
Children, 3 Children and 4+ Children. Personal employment indicators classify the respondent into various categories. If the person holds more than one job, he/she is classified based on the characteristics of the main job. The categories include being jobless (unemployed), working full-time, working part-time, being self-employed, having been retired, being a student, being housewife, or other employment.

Country-level variables include an indicator variable to represent if the country was ever colonized. Past colonization experience of the country may have an impact on the attitudes toward democracy. ${ }^{4}$ Also included in the group of country attributes is the religious make-up of the country, measured by proportion of the population that is Muslim, proportion Catholic, proportion Protestant and the proportion that adheres to other religions. Religion is a major part of culture, and in countries with hierarchical religions such as Catholicism, Eastern Orthodoxy and Islam, it may be culturally more difficult to challenge the authority of office-holders in comparison to cultures with more individualistic or egalitarian religions such as Protestantism. Second, as argued by Treisman (2000), in religions such as Protestantism, which emerged as a reaction to a state-sponsored religion, there may be stronger emphasis on monitoring potential abuses of state officials. By contrast, in more traditional religions such as Islam or Catholicism, such a check-andbalance role may be absent.

Regressions also include the Human Development Index created by the United Nations Development Program (UNDP). The Human Development Index (HDI) is a composite index that measures the average achievements in a country in three basic dimensions of human development: a long and healthy life, as measured by life expectancy

\footnotetext{
${ }^{4}$ Feyrer and Sacerdote (2009) show that the colonial origins of a country influence its economic development.
} 
at birth; knowledge, as measured by the adult literacy rate and the combined gross enrolment ratio for primary, secondary and tertiary schools; and the standard of living, as measured by GDP per capita in purchasing power parity US dollars.

We control for the share of military expenditures in GDP to account for the differences in the government policies between more democratic and less democratic regimes. Specifically, if governments in countries with low levels of democracy require more suppressive mechanism to be able to keep competitors out of office, and such governments may spend a larger fraction of GDP on military. Further, leaders of such authoritarian regimes have greater incentives to avoid conflict with the military to keep the military as a political ally, in comparison to the leaders of democratic regimes. This is because, authoritarian leaders may want the support of military in case of a revolt or they may want to use the military as domestic police in the country (Mulligan, Gil and Sala-iMartin 2004).

The unemployment rate of the country is obtained mainly from the World Development Indicators of the World Bank. The other source of the unemployment rate is the International Labour Organization's KILM database. If the unemployment rate is not available for one country at a specific year through WDI, it is imputed by assigning either the most recent year's unemployment or the average of the closest years' unemployment rates for that country in WDI. If neither of the imputation methods work (such as in the cases when there was no recent years' unemployment rates for a country or no data was available in WDI), then the unemployment rate from KILM database is employed.

For each country we also have data on the level of democracy. This variable, 
obtained from Polity $\mathrm{IV}^{5}$, measures various aspects of democracy in the country including competitiveness of political participation, competitiveness of executive recruitment, constraints and limitations on chief executive's authority. The democracy index ranges from -10 to 10 , where a higher value represents a better-functioning democracy. ${ }^{6}$ The means and standard deviations of country characteristics are calculated by considering each countryyear as one observation.

\section{$\underline{\text { III. Results }}$}

Table 2 displays the marginal effect obtained from estimation of Equation (1) using probit. Standard errors, that are corrected for arbitrary covariance structure and that are adjusted for clustering within a country in a specific year, are reported in parentheses. Regressions also include time dummies to control for the fact that different countries are surveyed in different years, and continent fixed effects to control for unobservable characteristics that may be common to the countries in the same broad geographic area.

Column (1) reports the results of the model where the dependent variable is whether the respondent believes that democracy is bad for the economy. The second column displays the results of the models where the dependent variables are whether the respondent believes that democracies are indecisive and have too much squabbling. The third column pertains

\footnotetext{
${ }^{5}$ http://www.systemicpeace.org/polity/polity4.htm

${ }^{6}$ The data on democracy variable were not available for some countries for some years from the source. The democracy variable is completed by assigning the closest year's democracy index value in that country or that of the previous governing country. For example, the democracy scores of Belarus, Estonia, Latvia, Lithuania and Czechoslovakia in 1991 are assigned to Belarus, Estonia, Latvia, Lithuania and Czech Republic in 1990, respectively (and in 1991 for Czech Republic). Similarly, democracy index values for Russian Federation in 1992 and Slovakia in 1992 are assigned to the same countries in 1990 and 1991.
} 
to the model where the dependent variable indicates if the respondent believes that a strong leader who does not bother with the parliament and elections is good for the country.

Column (1) of Table 2 demonstrates that being jobless is associated with about a 5 percentage point increase in the propensity to declare that democracy is bad for the economy. Similarly, columns 2 and 3 show that if the individual is jobless, his/her propensity to indicate that democracies are indecisive or that a rogue leader can better manage the country goes up by 3 to 5 percentage points. Holding constant personal employment, a one percentage point increase in the unemployment rate of the country increases the propensity to declare that democracy is bad for the economy by 0.4 percentage points and that a rogue leader is desirable by 0.6 percentage points. That is, the extent of joblessness in the economy has an additional impact on the negative attitudes towards democracy. As expected, those who agree with the statement that democracy is not better than any other form of government (Democracy is Not Better=1) tend to indicate that democracies are bad for the economy, that democracies are indecisive, and that a rouge leader can better manage the country.

Individuals who live in households where household income is in the middle of the income distribution of the country are 2 percentage points less likely to reveal negative feelings towards the efficiency of democracy in comparison to individuals who live in households where the household income belongs to the bottom one-third of the income distribution (the left-out category). Individuals who belong to the richest one-third of the households of a country (High Income=1) are 3 to 5 percentage points less likely to reveal negative feelings toward the efficiency of democracy or for the desire to have a rouge leader. Education of the individual has a significantly negative impact on the propensity to 
have negative feelings toward democracy. Specifically, those who attended college or who have college degrees are about 12 percentage points less likely to indicate that democracies are bad for the economy in comparison to those who have an elementary school education or less. Those who have a secondary degree (Middle Education=1) are 5 percentage points less likely to give positive responses to the same question in comparison to those who are not educated. The same is true regarding preferences about other questions as revealed by columns 2 and 3. Thus, regardless of their joblessness situation, individuals' beliefs about the efficiency of democracy goes down the poorer they are and the less educated they are.

All else the same, retired people display stronger negative feelings towards democracy. While the unemployment rate of the country has an impact as discussed above, other economic indicators of the country, such as the extent of openness to international trade and the inflation rate, do not impact individuals' beliefs about democratic efficiency. The same is true for the Human Development Index. The impacts of ever having been colonized and that of military spending are positive in column (1), although the coefficient is not significantly different in models displayed in columns 2 and 3. As will be discussed below, the impact of colonization on people's preferences for democracy will change direction if the models are estimated by the level of democracy of the country. As the proportion of people who are Protestant in the country goes up, the propensity for disapproval of the effectiveness of democracy goes down.

\section{Political Misfits and Reverse Causality}

Consistent with our expectations, $\beta$ in Equation (1) is estimated to be positive, indicating that jobless individuals have less favorable perceptions of the effectiveness of 
democracy in comparison to the perceptions of those who have jobs. The model controls for individuals' general attitudes toward democracy, measured by the variable Democracy is Not Better. However, it is still possible that the results are driven by those individuals whose views about democracy are not in line with the majority view of the population and that they are jobless because of this political conflict. That is, causality may run from the opinions about the effectiveness of democracy to joblessness. A person who is a "political misfit” in a society may find it difficult to find a job. To control for this effect, we classify countries into two categories. The first group consists of countries with a high level of functioning democracy and the second group contains countries where the level of democracy is lower. Specifically, we divide countries into two groups depending on whether the democracy index is less than seven, or greater than or equal to seven. ${ }^{7}$ We create a dichotomous indicator, Dislikes Democracy in a Democratic Country, which takes the value of 1 if the person thinks that democracy is not the best form of government (Democracy is Not Better=1) but who lives in a country with high-level of democracy.

\footnotetext{
${ }^{7}$ The first groups ( Democracy<7) consists of Albania, Algeria, Bangladesh, Armenia, Belarus, China, Croatia, Estonia, Iran, Jordan, Republic of Korea, Mexico, Morocco, Nigeria, Pakistan, Peru, Russian Federation, Singapore, Zimbabwe, Uganda, Egypt, Tanzania. The second group (Democracy >=7) includes Albania, Argentina, Australia, Austria, Belgium, Brazil, Bulgaria, Canada, Chile, Colombia, Czech Republic, Denmark, Dominican Republic, El Salvador, Finland, France, Germany, Greece, Hungary, Iceland, India, Indonesia, Ireland, Italy, Japan, Republic of Korea, Latvia, Luxembourg, Malta, Mexico, Republic of Moldova, Netherlands, New Zealand, Norway, Pakistan, Peru, Philippines, Poland, Portugal, Romania, Slovenia, South Africa, Spain, Sweden, Switzerland, Turkey, Ukraine, Great Britain, United States, Uruguay, Venezuela. The countries Albania, Republic of Korea, Mexico, Pakistan and Peru appear in both high democracy and low democracy samples. This is because the two waves of interviews were conducted in these countries in different years and the level of democracy has changed between the two survey years. For example, the democracy index was 5 in Albania in 1998 and it rose to 7 in 2002; it was 6 in 1996 in the Republic of Korea and rose to 8 in 2001. The index took a value of 4 in 1996 for Mexico, but it rose to 8 in 2000 in that country. Democracy index was 7 in Pakistan in 1997 and it went down to -6 in 2001; and it was 1 in 1996 in Peru and rose to 9 in 2001.
} 
Similarly, the indicator variable Likes Democracy in a Less Democratic Country takes the value of 1 if the person lives in a country with low level of democracy, but thinks that democracy is the best form of government (Democracy is Not Better=0). The results obtained from the specification that includes these additional control variables are reported in Panel A of Table 3. In the interest if space only the coefficients and the corresponding standard errors of Joblessness the Unemployment Rate and the variables to indicate whether the person is a political misfit in his/her country are reported. This specification did not alter either the point estimates or their estimated standard errors. The panel B of Table 3 displays the results of the same specification with one difference. These results are obtained from the model which omits the country variables, but includes country fixed-effects instead. In this specification the coefficients of Jobless remain the same, but the impact of the country unemployment loses statistical significance and/or changes sign. We also estimated the models by excluding political misfits from the sample. That is, we analyzed the relationship between joblessness, unemployment rate and preferences for democracy in sample of individuals whose general feelings towards democracy are aligned with the society they live in. The results remained the same.

It is plausible that the impact of joblessness on the beliefs about the effectiveness of democracy is different in countries with low levels of democracy in comparison to countries with a high level of democracy. Therefore, we estimated the model separately for countries with low levels of democracy (Democracy<7) and for countries that have a high level of democracy (Democracy $\geq 7$ ). The results are presented in Tables $4 \mathrm{~A}$ and $4 \mathrm{~B}$. The 
specifications also include the indicator variable to identify if the respondent is a political misfit in his/her country. ${ }^{8}$

There are commonalities in the results that are obtained from countries with low and high-levels of democracy. For example, in both groups of countries joblessness of an individual has a negative influence on the feelings towards democratic efficiency. The impact is similar between the two group of countries. Although the marginal effect of joblessness is slightly larger in countries with high levels of democracy, so are the baselines in these countries. ${ }^{9}$ Being divorced, separated from the spouse or being a widow is also correlated with having negative feelings toward democracy; and the same is true of being retired.

There are also interesting contrasts between the results obtained from the two groups of countries. The unemployment rate has a strong impact on the feelings toward democracy for people in countries where the level of democracy is low (Table 4A), while the unemployment rate has no impact on people’s feelings towards the effectiveness of democracy in countries where the level of democracy is high (Table 4B). The former group consists of mostly, but not exclusively, of developing countries (see footnote 7), where the societies are collectivist, rather than individualistic (Mocan 2008). Thus, an increase in the unemployment rate may have a direct impact on the utility of the individual based on otherregarding preferences. It could also be the case that an increase in the unemployment rate

\footnotetext{
${ }^{8}$ The results did not change appreciably when we classified the countries based on the democracy cutoffs at 6 or 8 ).

${ }^{9}$ In countries with low levels of democracy, the proportion of people who indicated that democracy is bad for the economy is 0.33 , while it is 0.35 in the countries with high levels of democracy. The proportion of people who indicated that democracies are indecisive is 0.47 in the former group and it is 0.54 in the latter. Finally the proportion who prefers a rogue leader is 0.33 in the former group and 0.37 in the latter.
} 
triggers a higher level of anxiety in these countries because an increase in the unemployment rate may be associated with a larger degree of uncertainty about the future of the labor market in these countries.

In the group of countries where democracy is higher, having ever been a colony has no impact on the extent of people's feelings towards democracy. On the other hand, among the group of countries with low levels of democracy, having been colonized in the past decreases the propensity to indicate that democracies are bad for the economy. In countries with low levels of democracy, the propensity to respond in the affirmative that democracies are bad for the economy, democracies are indecisive, and a rouge leader is good for the country is lower if the individual's household income belongs to the top one-third of the country's income distribution and if the individual has attended or completed college. In comparison, in the sample of people who live in countries with high levels of democracy, a switch in household income from the lowest third of the distribution to the middle income group is associated with a reduction in negative feelings towards the effectiveness of democracy. The same is effect is achieved with an increase in personal education from the lowest echelon (elementary education or less) to the secondary education level. This means that in countries with low levels of democracy, a change in feelings towards the effectiveness of democracy can only be achieved with a more substantial increase in personal education and household income in comparison to countries where high levels of democracy. 


\section{Potential for a Spurious Relationship}

The specifications we estimated include a large number of country-level variables as well as a large number of personal attributes, including the individuals' general feelings towards democracy. To analyze the significance of a potential reverse causality, we also ran specifications that included a variable that gauges the extent of the mismatch between the individual's general feelings towards democracy and the level of democracy of the country as described above. In all specifications the impact of joblessness on the perceptions of the effectiveness of democracy remained robust. Nevertheless, we cannot rule out the possibility that preferences for the effectiveness of democracy are indications of a general feeling towards the government or towards public policy. If that is the case, what we identify as the impact of joblessness on attitudes towards the effectiveness of democracy could be nothing but the relationship between joblessness and general unhappiness about the government or governance of the country. To investigate if this is the case, we estimate the same models by using three different dependent variables. These dependent variables aim to gauge the extent of confidence people reveal in the government and the level of satisfaction with the manner in which country's affairs are handled. The first variable is based on the question "Could you tell me how much confidence you have in the government?” Potential answers are: a great deal of confidence, quite a lot of confidence, not very much confidence or none at all. A dummy variable is created that takes the value of one if the individual indicated he/she did not have very much confidence or had no confidence in the government. The second question aims to measure the extent of dissatisfaction with the government, where people were asked: "How satisfied are you with the way the people now in national office are handling the country's affairs? Would you say 
you are very satisfied, fairly satisfied, fairly dissatisfied or very dissatisfied?” We classified individuals as dissatisfied with the people in the national office if they indicated that they were fairly dissatisfied or very dissatisfied. The third variable is based on the question: “Generally speaking, would you say that this country is run by a few big interests looking out for themselves, or that it is run for the benefit of all the people?” A dichotomous variable, which takes the value of 1 is created if the respondent indicated that the country was run by a few big interests.

We ran probit models using these three indicators as dependent variables. We employed the same specifications as in Tables 2 and 3, using the same samples. That is, we included individuals that were part of the regressions in Tables 2 and 3 and who also answered the three questions above. ${ }^{10}$ The results are displayed in Table 5. We ran two specifications for each question. Panel A displays the results which are based on the specification presented in Table 2, and Panel B displays the results which include the variable which measures if the person is political misfit in his/her country. The coefficient of Joblessness is not different from zero in any specification in Table 5. This indicates that the impact of being jobless on the beliefs about the effectiveness of democracy, displayed in Tables 2-4, is not likely to be an artifact of a general displeasure towards government, but rather, it is targeted towards democracy.

\section{Duration of Joblessness}

It is possible that the impact of joblessness on the perceptions about the effectiveness of democracy changes by the duration of joblessness. That is, individuals' attitudes may

\footnotetext{
${ }^{10}$ Using all individuals who answered these two questions regardless of whether they answered the questions about democratic efficiency (which generated a 10\% increase in sample size) did not alter the results.
} 
depend on how long they have been without a job. To investigate if this is the case, we replace the variable Jobless with three mutually exclusive dummy variables: Jobless-Less than 6 months, Jobless 6 months to 1 year, and Jobless: More than 1 year. These variables identify whether the person was unemployed for less than six months, six months to a year, or more than one year, respectively. The information about the duration of joblessness was based on the following question: “For how long are you unemployed?” The responded could choose among six categories ranging from "less than half a year" to "more than two years". This question was asked in 1999 in the overwhelming majority of cases, and it was asked only in European countries. Therefore, the sample used in this analysis is smaller and is not comparable to the sample used in previous analyses. ${ }^{11}$ Nevertheless the results, displayed in Table 6 are informative, and they indicate that in the sample of Europeans, the duration of joblessness matters. More specifically, the perceptions about the effectiveness of democracy and the desire for a rouge leader impact of joblessness is driven by long-term unemployment. Short-term unemployment (less than six months) may be voluntary or frictional, which would not prompt negative feelings towards democracy. Table 6 shows that those who are unemployed for less than six months do not have systematically different perceptions about the effectiveness of democracy in comparison to those who have jobs. The same is true for those who are unemployed for a period of six months to a year. However, those who are unemployed for more than one year are significantly more likely to indicate that democracy is bad for the economy, that democracies are indecisive and involve too much quibbling, and that a rouge leader is preferable. Thus, the results obtained from

${ }^{11}$ The sample covers the following countries: Austria, Belarus, Belgium, Bulgaria, Croatia, Czech Republic, Denmark, Estonia, Finland, France, Germany, Greece, Great Britain, Hungary, Ireland, Italy, Latvia, Netherlands, Poland, Portugal, Romania, Russian Federation, Slovenia, Spain, and Turkey. 
the European sample indicate that long-term joblessness alters people's perceptions of democracy.

\section{$\underline{\text { IV. Summary and conclusions }}$}

This paper employs micro data on more than 130,000 people from 69 countries to investigate the relationship between personal joblessness of the individuals and their perceptions of the effectiveness of democracy. We control for a large set of personal characteristics, country attributes, as well as individuals' general feelings towards democracy. In non-experimental data sets, such as the one used in this paper, one can never be certain about the true cause-and-effect relationship between the variables. For example, reverse causality is possible; i.e., an individual's perceptions about the effectiveness of democracy may impact his/her employability. This could especially be the case if the person is a political misfit in his/her country. For example, a person may believe that democracy is not a desirable form of government. This person would be a political misfit if he/she lives in country that has a high level of democracy, and being a political misfit may prevent the person from finding or holding a job. To avoid a potential bias that may emerge through this channel, we adjust for the alignment of the person's general feelings towards democracy with the extent of the democracy in the country.

We find that observationally identical individuals who live in the same country have different perceptions about the effectiveness of democracy if they differ in their joblessness experience. Specifically, being jobless increases people’s propensity to declare that economic system runs badly in democracies, that democracies are indecisive and involve too much quibbling, and that a leader who does not bother with the parliament and elections 
is preferable. This impact of joblessness exists both in countries with low levels of democracy and in countries with high levels of democracy. Information available in a subsample of data (people who live in European countries) indicates that the source of discontent with democracy is joblessness that lasts longer than one year. An increase in the unemployment rate of the country evokes negative feelings about the performance of democracy for individuals who live in countries with low levels of democracy. We also find that well-educated and wealthier individuals are less likely to indicate that democracies are ineffective, regardless of joblessness.

When we employ alternative dependent variables such as whether the person has confidence in the government, whether the person is satisfied with the way people in the national office are handling the country's affairs, and whether the person believes that the country is run by a few big interests looking out for themselves, we find that joblessness has no impact on these opinions. This suggests that the impact of joblessness on negative perceptions about the effectiveness of democracy is not a reflection of a general disapproval of the government.

Given the research that indicates a strong impact of democratization and institutional quality on economic development, it is important to identify the determinants of democratization. The results of this paper suggest that the beliefs about the effectiveness of democracy as system of governance are shaped by personal joblessness experience of the individuals. This in turn implies that periods of high unemployment and joblessness could hinder the development of democracy, or threaten its existence. 
Table 1

Summary Statistics and Descriptions

\begin{tabular}{|c|c|c|c|}
\hline Variable & Description & Mean & Std. Dev. \\
\hline $\begin{array}{l}\text { Democracy is Bad for the } \\
\text { Economy }\end{array}$ & $\begin{array}{l}=1 \text { if the individual agrees or strongly agrees } \\
\text { that in democracies the economic system runs } \\
\text { badly and zero otherwise. (A) }\end{array}$ & 0.340 & 0.474 \\
\hline $\begin{array}{l}\text { Democracies are } \\
\text { Indecisive }\end{array}$ & $\begin{array}{l}=1 \text { if the individual agrees or strongly agrees } \\
\text { that democracies are indecisive and have too } \\
\text { much squabbling and zero otherwise. (A) }\end{array}$ & 0.513 & 0.500 \\
\hline Rogue Leader & $\begin{array}{l}=1 \text { if the individual believes that a strong } \\
\text { leader who does not have to bother with } \\
\text { parliament and elections is good or very good } \\
\text { for governing the country. (A) }\end{array}$ & 0.353 & 0.478 \\
\hline Jobless & $=1$ if the individual is unemployed. (A) & 0.088 & 0.284 \\
\hline Unemployment Rate $^{\mathrm{a}}$ & Unemployment Rate (F) & 9.571 & 6.185 \\
\hline Democracy is Not Better & $\begin{array}{l}=1 \text { if the individual disagrees or strongly } \\
\text { disagrees to "Democracy may have problems } \\
\text { but it's better than any other form of } \\
\text { government" (A). }\end{array}$ & 0.127 & 0.333 \\
\hline $\begin{array}{l}\text { Dislikes Democracy in a } \\
\text { Democratic Country }\end{array}$ & $\begin{array}{l}=1 \text { if the individual disagrees or strongly } \\
\text { disagrees to "Democracy may have problems } \\
\text { but it's better than any other form of } \\
\text { government" and lives in a democratic country } \\
\text { (A). }\end{array}$ & 0.080 & 0.271 \\
\hline $\begin{array}{l}\text { Likes Democracy in a Less } \\
\text { Democratic Country }\end{array}$ & $\begin{array}{l}=1 \text { if the individual agrees or strongly agrees to } \\
\text { "Democracy may have problems but it's better } \\
\text { than any other form of government" and lives } \\
\text { in a less democratic country (A). }\end{array}$ & 0.242 & 0.428 \\
\hline Female & Dummy for females. (A) & 0.505 & 0.500 \\
\hline Age & Age of the individual. Scaled by 0.1. (A) & 4.071 & 1.602 \\
\hline Low Income & $\begin{array}{l}=1 \text { if the individual's household income is less } \\
\text { than the } 33^{\text {th }} \text { percentile of the income } \\
\text { distribution in his/her country. (A) }\end{array}$ & 0.335 & 0.472 \\
\hline Medium Income & $\begin{array}{l}=1 \text { if the individual's household income is } \\
\text { between } 33^{\text {th }} \text { and } 67^{\text {th }} \text { percentiles of the income } \\
\text { distribution in his/her country. (A) }\end{array}$ & 0.359 & 0.480 \\
\hline High Income & $\begin{array}{l}=1 \text { if the individual's household income is } \\
\text { greater than } 67^{\text {th }} \text { percentile of the income } \\
\text { distribution in his/her country. (A) }\end{array}$ & 0.306 & 0.461 \\
\hline Low Education & $\begin{array}{l}=1 \text { if at most the individual either has } \\
\text { inadequately or fully completed elementary } \\
\text { education or has not adequately completed } \\
\text { secondary school. (A) }\end{array}$ & 0.356 & 0.479 \\
\hline
\end{tabular}


Table 1 (continued)

\begin{tabular}{|c|c|c|c|}
\hline Variable & Description & Mean & Std. Dev. \\
\hline Middle Education & $\begin{array}{l}=1 \text { if the individual has completed secondary } \\
\text { school but not tertiary. (A) }\end{array}$ & 0.429 & 0.495 \\
\hline High Education & $\begin{array}{l}=1 \text { if the individual has completed tertiary } \\
\text { education in full or in part. (A) }\end{array}$ & 0.215 & 0.411 \\
\hline Single & $=1$ if the individual is single. (A) & 0.254 & 0.435 \\
\hline Married & $\begin{array}{l}=1 \text { if the individual is married or living } \\
\text { together with a partner. (A) }\end{array}$ & 0.627 & 0.484 \\
\hline Divorced/Widowed & $\begin{array}{l}=1 \text { if the individual is separated divorced or } \\
\text { widowed. (A) }\end{array}$ & 0.119 & 0.324 \\
\hline Full-time & $=1$ if the individual is working full-time. (A) & 0.371 & 0.483 \\
\hline Part-time & $=1$ if the individual is working part-time. (A) & 0.075 & 0.263 \\
\hline Self-employed & $=1$ if the individual is self-employed. (A) & 0.098 & 0.297 \\
\hline Retired & $=1$ if the individual is retired. (A) & 0.136 & 0.343 \\
\hline Housewife & $=1$ if the individual is a housewife. (A) & 0.137 & 0.344 \\
\hline Student & $=1$ if the individual is a student. (A) & 0.077 & 0.266 \\
\hline Other Employed & $\begin{array}{l}=1 \text { if employment status of the individual is } \\
\text { something other than those listed. (A) }\end{array}$ & 0.018 & 0.134 \\
\hline No Children & $=1$ if the individual has no children. (A) & 0.289 & 0.453 \\
\hline 1 Child & $=1$ if the individual has 1 child. (A) & 0.163 & 0.370 \\
\hline 2 Children & $=1$ if the individual has 2 children. (A) & 0.266 & 0.442 \\
\hline 3 Children & $=1$ if the individual has 3 children. (A) & 0.139 & 0.346 \\
\hline 4+ Children & $=1$ if the individual has 4 or more children. (A) & 0.143 & 0.350 \\
\hline Democracy $^{\mathrm{a}}$ & $\begin{array}{l}\text { Extent of Democracy in a country obtained } \\
\text { from the Combined Polity Score of POLITY } \\
\text { IV. Ranges from - } 10 \text { (Least democratic) to } 10 \\
\text { (Most democratic). (I) }\end{array}$ & 6.248 & 5.226 \\
\hline Country Ever Colonized $^{\text {a }}$ & $\begin{array}{l}=1 \text { if the country where the individual lives has } \\
\text { ever been colonized. (B) }\end{array}$ & 0.385 & 0.478 \\
\hline $\mathrm{HDI}^{\mathrm{a}}$ & $\begin{array}{l}\text { Human Development Index. A composite } \\
\text { index that measures the average achievements } \\
\text { in a country in three basic dimensions life } \\
\text { expectancy at birth, the adult literacy rate and } \\
\text { the combined gross enrolment ratio for } \\
\text { primary, secondary and } \\
\text { tertiary schools and real GDP per capita (E) }\end{array}$ & 79.400 & 12.935 \\
\hline Openness to Trade ${ }^{a}$ & $\begin{array}{l}\text { Total trade (exports plus imports) as a } \\
\text { percentage of GDP in } 2000 \text { prices. (G) }\end{array}$ & 75.697 & 51.329 \\
\hline Military Expenditure ${ }^{\text {a }}$ & Military expenditures as a \% of GDP. (H) & 2.223 & 1.549 \\
\hline Inflation Rate ${ }^{a}$ & Inflation Rate calculated from GDP deflator. & 0.245 & 0.959 \\
\hline$\%$ Muslim Population ${ }^{\text {a }}$ & Percent of population who are Muslims. (D) & 13.685 & 30.380 \\
\hline
\end{tabular}


Table 1 (concluded)

\begin{tabular}{llcc}
\hline Variable & Description & Mean & Std. Dev. \\
\hline \% Catholic Population $^{\text {a }}$ \% Protestant Population $^{\text {a }}$ & Percent of population who are Catholics. (D) & 37.047 & 39.246 \\
\% Other Religion $^{\text {a }}$ & Percent of population who are Protestants. (D) & 13.906 & 24.968 \\
Population $^{\text {a }}$ & $\begin{array}{l}\text { Percent of population who are of other } \\
\text { denominations. (D) }\end{array}$ & 35.362 & 34.915 \\
Europe $^{\text {a }}$ & $=1$ if the country is located in Europe. & 0.529 & 0.502 \\
Africa $^{\text {a }}$ & $=1$ if the country located in Africa. & 0.087 & 0.283 \\
Asia $^{\text {a }}$ & $=1$ if the country is located in Asia. & 0.183 & 0.388 \\
South America $^{\text {a }}$ & $=1$ if the country is located in South America. & 0.135 & 0.343 \\
Oceania $^{\text {a }}$ & $=1$ if the country is located in Oceania. & 0.019 & 0.138 \\
North America $^{\text {a }}$ & $=1$ if the country is located in North America. & 0.048 & 0.215 \\
\hline
\end{tabular}

Numbers of non-missing observations for "Democracy is Bad for the Economy", "Democracies are Indecisive" and "A strong Leader can better manage the country" are 118,365, 120,739 and 131,615, respectively. For the rest of the variables, the number of non-missing observations range from 115,159 and 131,540 (except for controls misfit and preferences about democracy for which the numbers of non-missing observations is around 110,000).

Sources of the variables used are presented below.

(A) World Values Survey. The original sources of the variables used are indicated in parenthesis after the dash.

(B) Hadenius, A. and Teorell, J. 2005. “Assessing Alternative Indices of Democracy”, C\&M Working Papers

6, IPSA, August 2005.

(C) Vanhanen, T. 2003b. Democratization and Power Resources 1850-2000 [computer file]. FSD1216, version 1.0 (2003-03-10). Tampere : Finnish Social Science Data Archive [distributor].

(D) La Porta, R., López-de-Silanes, F., Shleifer, A.. and Vishny, R. 1999. The Quality of Government. Journal of Law, Economics and Organization, 15(1): 222-279.

(E) United Nations Development Program (UNDP). http://hdr.undp.org/en/statistics/data/

(F) World Bank's World Development Indicators, International Labour Organization's KILM database. If the unemployment rate was not available for one country at a specific year, it is imputed by using either the most recent year's unemployment rate or the average of the closest year's unemployment rate. If neither of the imputations work, then the unemployment rate from KILM database is employed.

(G) Penn World tables 6.2

(H) World Bank's World Development Indicators

(I) POLITY IV. http://www.systemicpeace.org/polity/polity4.htm. The data on democracy variable were not available for some countries for some years from the source. The democracy variable is completed by assigning the closest year's democracy index value in that country or that of the previous governing country. See footnote 6 in the text for details.

a: The descriptive statistics of the country level variables are calculated using each country-year as one observation. 
Table 2

Influence of Joblessness on Perceptions about Performance of Democracy

\begin{tabular}{|c|c|c|c|}
\hline & (1) & (2) & (3) \\
\hline & $\begin{array}{l}\text { Democracy is Bad for } \\
\text { the Economy }\end{array}$ & $\begin{array}{l}\text { Democracies are } \\
\text { Indecisive }\end{array}$ & $\begin{array}{l}\text { Rogue } \\
\text { Leader }\end{array}$ \\
\hline Jobless & $\begin{array}{c}0.049^{* * *} \\
(0.008)\end{array}$ & $\begin{array}{c}0.028^{* * *} \\
(0.011)\end{array}$ & $\begin{array}{c}0.054^{* * *} \\
(0.011)\end{array}$ \\
\hline Unemployment Rate & $\begin{array}{c}0.004^{* *} \\
(0.002)\end{array}$ & $\begin{array}{c}0.002 \\
(0.002)\end{array}$ & $\begin{array}{c}0.006 * * * \\
(0.002)\end{array}$ \\
\hline Democracy is Not Better & $\begin{array}{c}0.224 * * * \\
(0.036)\end{array}$ & $\begin{array}{c}0.160 * * * \\
(0.030)\end{array}$ & $\begin{array}{c}0.178^{* * *} \\
(0.018)\end{array}$ \\
\hline Female & $\begin{array}{c}0.024 * * * \\
(0.004)\end{array}$ & $\begin{array}{c}0.002 \\
(0.006)\end{array}$ & $\begin{array}{c}-0.015 * * * \\
(0.005)\end{array}$ \\
\hline Age & $\begin{array}{c}-0.006^{* *} \\
(0.003)\end{array}$ & $\begin{array}{l}-0.000 \\
(0.003)\end{array}$ & $\begin{array}{c}-0.006^{* *} \\
(0.003)\end{array}$ \\
\hline Medium Income & $\begin{array}{c}-0.020 * * * \\
(0.007)\end{array}$ & $\begin{array}{c}-0.020^{* * *} \\
(0.007)\end{array}$ & $\begin{array}{c}-0.018^{* * *} \\
(0.006)\end{array}$ \\
\hline High Income & $\begin{array}{c}-0.050 * * * \\
(0.010)\end{array}$ & $\begin{array}{c}-0.037 * * * \\
(0.012)\end{array}$ & $\begin{array}{c}-0.030^{* * *} \\
(0.010)\end{array}$ \\
\hline Middle Education & $\begin{array}{c}-0.052^{* * *} \\
(0.011)\end{array}$ & $\begin{array}{c}-0.039 * * * \\
(0.012)\end{array}$ & $\begin{array}{c}-0.035^{* * *} \\
(0.010)\end{array}$ \\
\hline High Education & $\begin{array}{c}-0.124 * * * \\
(0.014)\end{array}$ & $\begin{array}{c}-0.108^{* * *} \\
(0.015)\end{array}$ & $\begin{array}{c}-0.086^{* * *} \\
(0.015)\end{array}$ \\
\hline Married & $\begin{array}{c}0.008 \\
(0.008)\end{array}$ & $\begin{array}{l}0.016^{*} \\
(0.009)\end{array}$ & $\begin{array}{c}0.013 \\
(0.009)\end{array}$ \\
\hline Divorced/Widowed & $\begin{array}{c}0.026 * * \\
(0.011)\end{array}$ & $\begin{array}{c}0.039 * * * \\
(0.010)\end{array}$ & $\begin{array}{l}0.028 * * \\
(0.011)\end{array}$ \\
\hline Part-time & $\begin{array}{c}0.014 \\
(0.009)\end{array}$ & $\begin{array}{c}0.007 \\
(0.009)\end{array}$ & $\begin{array}{c}0.014 \\
(0.010)\end{array}$ \\
\hline Self-employed & $\begin{array}{l}-0.003 \\
(0.010)\end{array}$ & $\begin{array}{c}0.009 \\
(0.011)\end{array}$ & $\begin{array}{c}0.008 \\
(0.011)\end{array}$ \\
\hline Retired & $\begin{array}{c}0.048 * * * \\
(0.008)\end{array}$ & $\begin{array}{c}0.053^{* * * *} \\
(0.009)\end{array}$ & $\begin{array}{c}0.043^{* * *} \\
(0.009)\end{array}$ \\
\hline Housewife & $\begin{array}{l}-0.014 \\
(0.010)\end{array}$ & $\begin{array}{c}-0.023^{* *} \\
(0.012)\end{array}$ & $\begin{array}{c}0.029 * * \\
(0.014)\end{array}$ \\
\hline Student & $\begin{array}{l}-0.006 \\
(0.010)\end{array}$ & $\begin{array}{c}0.001 \\
(0.013)\end{array}$ & $\begin{array}{c}0.005 \\
(0.010)\end{array}$ \\
\hline Other Employed & $\begin{array}{l}-0.010 \\
(0.018)\end{array}$ & $\begin{array}{l}-0.018 \\
(0.019)\end{array}$ & $\begin{array}{c}0.003 \\
(0.020)\end{array}$ \\
\hline
\end{tabular}


Table 2 (concluded)

\begin{tabular}{lccc}
\hline & $(1)$ & $(2)$ & $(3)$ \\
\hline & $\begin{array}{c}\text { Democracy is Bad for } \\
\text { the Economy }\end{array}$ & $\begin{array}{c}\text { Democracies are } \\
\text { Indecisive }\end{array}$ & $\begin{array}{c}\text { Rogue } \\
\text { Leader }\end{array}$ \\
\hline Child & 0.007 & -0.001 & 0.013 \\
& $(0.008)$ & $(0.008)$ & $(0.010)$ \\
Children & $0.014^{*}$ & 0.005 & 0.009 \\
& $(0.008)$ & $(0.009)$ & $(0.010)$ \\
4+ Children & 0.008 & 0.002 & 0.005 \\
& $(0.010)$ & $(0.011)$ & $(0.011)$ \\
HDI & 0.003 & -0.020 & $0.025^{*}$ \\
& $(0.012)$ & $(0.013)$ & $(0.014)$ \\
Openness to Trade & -0.001 & 0.002 & -0.002 \\
& $(0.001)$ & $(0.002)$ & $(0.002)$ \\
Military Expenditure & -0.000 & -0.000 & 0.000 \\
& $(0.000)$ & $(0.000)$ & $(0.000)$ \\
Inflation Rate & $0.017^{* *}$ & 0.005 & -0.004 \\
& $(0.008)$ & $(0.011)$ & $(0.010)$ \\
Country Ever Colonized & 0.013 & 0.002 & 0.018 \\
& $(0.014)$ & $(0.014)$ & $(0.012)$ \\
\% Muslim & $0.169^{* * *}$ & 0.088 & 0.093 \\
& $(0.058)$ & $(0.065)$ & $(0.076)$ \\
\% Catholic & $-0.002^{* * *}$ & -0.001 & -0.001 \\
& $(0.000)$ & $(0.001)$ & $(0.001)$ \\
\% Protestant & -0.001 & -0.000 & $-0.001 * *$ \\
& $(0.001)$ & $(0.001)$ & $(0.001)$ \\
Observations & $-0.002^{* * *}$ & $-0.002^{* *}$ & $-0.003^{* * *}$ \\
& $(0.001)$ & $(0.001)$ & $(0.001)$ \\
\hline
\end{tabular}

Notes - The dependent variables, listed at the top of rows 1 to 3 , take the value of 1 if the individual agrees or strongly agrees to the statements "Democracy is Bad for the Economy," "Democracies are Indecisive" and "A strong leader can better manage the country," respectively. The descriptions of the other variables are presented in Table 1 . All regressions include year dummies as well as continent fixed effects. ***, ** and * indicate significance at the $1 \%, 5 \%$ and $10 \%$ levels, respectively. Standard errors are clustered at the countryyear level. 
Table 3

Influence of Joblessness on Perceptions about Performance of Democracy Controlling for Political Misfit

Panel A: Models with Country Characteristics

\begin{tabular}{lccc}
\hline & $(1)$ & $(2)$ & $(3)$ \\
\hline & $\begin{array}{c}\text { Democracy is Bad for } \\
\text { the Economy }\end{array}$ & $\begin{array}{c}\text { Democracies are } \\
\text { Indecisive }\end{array}$ & Rogue Leader \\
\hline Jobless & $0.045^{* * *}$ & $0.025^{* *}$ & $0.049^{* * *}$ \\
& $(0.008)$ & $(0.011)$ & $(0.010)$ \\
Unemployment Rate & $0.005^{* * *}$ & 0.002 & $0.007^{* * *}$ \\
& $(0.002)$ & $(0.002)$ & $(0.002)$ \\
Dislikes Democracy in a & $0.212^{* * *}$ & $0.128^{* * *}$ & $0.175^{* * *}$ \\
Democratic country & $(0.027)$ & $(0.026)$ & $(0.016)$ \\
Likes Democracy in a Less & $-0.091^{* * *}$ & $-0.112^{* * *}$ & $-0.104^{* * *}$ \\
Democratic country & $(0.031)$ & $(0.031)$ & $(0.031)$ \\
\hline Observations & 118,365 & 120,739 & 131,615 \\
\hline
\end{tabular}

Panel B: Models with Country Fixed Effects

\begin{tabular}{lccc}
\hline & $(1)$ & $(2)$ & $(3)$ \\
\hline & $\begin{array}{c}\text { Democracy is Bad for } \\
\text { the Economy }\end{array}$ & $\begin{array}{c}\text { Democracies are } \\
\text { Indecisive }\end{array}$ & Rogue Leader \\
\hline Jobless & $0.041^{* * *}$ & $0.025^{* * *}$ & $0.033^{* * *}$ \\
Unemployment Rate & $(0.007)$ & $(0.008)$ & $(0.007)$ \\
& -0.000 & $-0.005^{*}$ & 0.004 \\
Dislikes Democracy in a & $(0.005)$ & $(0.003)$ & $(0.005)$ \\
Democratic country & $0.219^{* * *}$ & $0.140^{* * *}$ & $0.166^{* * *}$ \\
Likes Democracy in a Less & $(0.028)$ & $(0.025)$ & $(0.014)$ \\
Democratic country & $-0.125^{* *}$ & $-0.126^{* *}$ & -0.036 \\
\hline Observations & $(0.053)$ & $(0.059)$ & $(0.030)$ \\
\hline
\end{tabular}

Notes - The dependent variables, listed at the top of rows 1 to 3 , take the value of 1 if the individual agrees or strongly agrees to the statements "Democracy is Bad for the Economy," "Democracies are Indecisive" and "A strong Leader can better manage the country," respectively. The descriptions of the other variables are presented in Table 1. All regressions include individual level variables, year dummies as well as continent fixed effects as in Table 2. The models in Panel A and B include country characteristics and country fixed effects, respectively. ${ }^{* * *},{ }^{* *}$ and $*$ indicate significance at the $1 \%, 5 \%$ and $10 \%$ levels, respectively. Standard errors are clustered at the country-year level. 
Table 4A

Influence of Joblessness on Perceptions about Performance of Democracy In Less Democratic Countries (Democracy<7)

\begin{tabular}{|c|c|c|c|}
\hline & (1) & (2) & (3) \\
\hline & $\begin{array}{c}\text { Democracy is Bad for } \\
\text { the Economy }\end{array}$ & $\begin{array}{l}\text { Democracies are } \\
\text { Indecisive }\end{array}$ & Rogue Leader \\
\hline \multirow[t]{2}{*}{ Jobless } & $0.040 * * *$ & $0.023^{*}$ & 0.004 \\
\hline & $(0.010)$ & $(0.013)$ & $(0.013)$ \\
\hline \multirow[t]{2}{*}{ Unemployment Rate } & $0.007 * * *$ & $0.013 * * *$ & $0.019 * * *$ \\
\hline & $(0.002)$ & $(0.003)$ & $(0.003)$ \\
\hline Likes Democracy in a Less & $-0.178 * *$ & $-0.152 *$ & $-0.128 * * *$ \\
\hline Democratic country & $(0.089)$ & $(0.083)$ & $(0.044)$ \\
\hline \multirow[t]{2}{*}{ Female } & $0.027 * * *$ & 0.006 & -0.001 \\
\hline & $(0.008)$ & $(0.011)$ & $(0.010)$ \\
\hline \multirow[t]{2}{*}{ Age } & 0.006 & $0.010 *$ & 0.004 \\
\hline & $(0.005)$ & $(0.005)$ & $(0.004)$ \\
\hline \multirow[t]{2}{*}{ Medium Income } & -0.022 & $-0.021 *$ & -0.011 \\
\hline & $(0.015)$ & $(0.012)$ & $(0.012)$ \\
\hline \multirow[t]{2}{*}{ High Income } & $-0.045 * *$ & $-0.056 * * *$ & -0.026 \\
\hline & $(0.019)$ & $(0.018)$ & $(0.016)$ \\
\hline \multirow[t]{2}{*}{ Middle Education } & -0.016 & 0.002 & 0.005 \\
\hline & $(0.015)$ & $(0.018)$ & $(0.018)$ \\
\hline \multirow[t]{2}{*}{ High Education } & $-0.070 * * *$ & -0.043 & $-0.051^{*}$ \\
\hline & $(0.022)$ & $(0.028)$ & $(0.027)$ \\
\hline \multirow[t]{2}{*}{ Married } & 0.018 & -0.000 & 0.001 \\
\hline & $(0.012)$ & $(0.018)$ & $(0.015)$ \\
\hline \multirow[t]{2}{*}{ Divorced/Widowed } & $0.061^{* * *}$ & $0.040 *$ & 0.011 \\
\hline & $(0.017)$ & $(0.022)$ & $(0.016)$ \\
\hline \multirow[t]{2}{*}{ Part-time } & 0.031 & 0.006 & 0.011 \\
\hline & $(0.021)$ & $(0.021)$ & $(0.024)$ \\
\hline \multirow[t]{2}{*}{ Self-employed } & 0.024 & 0.014 & -0.001 \\
\hline & $(0.017)$ & $(0.016)$ & $(0.014)$ \\
\hline \multirow[t]{2}{*}{ Retired } & $0.035 * *$ & $0.040 * * *$ & $0.039 *$ \\
\hline & $(0.014)$ & $(0.015)$ & $(0.021)$ \\
\hline \multirow[t]{2}{*}{ Housewife } & 0.006 & -0.014 & 0.009 \\
\hline & $(0.017)$ & $(0.018)$ & $(0.016)$ \\
\hline \multirow[t]{2}{*}{ Student } & 0.012 & -0.012 & $0.033 * *$ \\
\hline & $(0.017)$ & $(0.012)$ & $(0.015)$ \\
\hline \multirow[t]{2}{*}{ Other Employed } & 0.010 & -0.027 & 0.012 \\
\hline & $(0.033)$ & $(0.033)$ & $(0.024)$ \\
\hline
\end{tabular}


Table 4A (concluded)

\begin{tabular}{|c|c|c|c|}
\hline & $(1)$ & $(2)$ & (3) \\
\hline & $\begin{array}{l}\text { Democracy is Bad for } \\
\text { the Economy }\end{array}$ & $\begin{array}{l}\text { Democracies are } \\
\text { Indecisive }\end{array}$ & Rogue Leader \\
\hline 1 Child & $\begin{array}{l}-0.012 \\
(0.011)\end{array}$ & $\begin{array}{l}-0.013 \\
(0.016)\end{array}$ & $\begin{array}{l}-0.000 \\
(0.015)\end{array}$ \\
\hline 2 Children & $\begin{array}{c}0.009 \\
(0.014)\end{array}$ & $\begin{array}{l}-0.001 \\
(0.013)\end{array}$ & $\begin{array}{c}0.016 \\
(0.015)\end{array}$ \\
\hline 3 Children & $\begin{array}{c}0.021 \\
(0.016)\end{array}$ & $\begin{array}{c}0.015 \\
(0.018)\end{array}$ & $\begin{array}{c}0.014 \\
(0.022)\end{array}$ \\
\hline 4+ Children & $\begin{array}{l}-0.017 \\
(0.015)\end{array}$ & $\begin{array}{c}-0.029 * * \\
(0.013)\end{array}$ & $\begin{array}{c}0.020 \\
(0.025)\end{array}$ \\
\hline HDI & $\begin{array}{c}-0.004^{* * *} \\
(0.002)\end{array}$ & $\begin{array}{c}0.007 \\
(0.004)\end{array}$ & $\begin{array}{l}-0.001 \\
(0.003)\end{array}$ \\
\hline Openness to Trade & $\begin{array}{c}0.000 \\
(0.000)\end{array}$ & $\begin{array}{l}-0.000 \\
(0.001)\end{array}$ & $\begin{array}{l}-0.000 \\
(0.000)\end{array}$ \\
\hline Military Expenditure & $\begin{array}{l}0.031^{* *} \\
(0.012)\end{array}$ & $\begin{array}{l}-0.057^{*} \\
(0.030)\end{array}$ & $\begin{array}{c}0.018 \\
(0.021)\end{array}$ \\
\hline Inflation Rate & $\begin{array}{c}0.014 \\
(0.037)\end{array}$ & $\begin{array}{l}0.120 * * \\
(0.058)\end{array}$ & $\begin{array}{c}0.116 \\
(0.095)\end{array}$ \\
\hline Country Ever Colonized & $\begin{array}{c}-0.172 * * * \\
(0.033)\end{array}$ & $\begin{array}{l}-0.060 \\
(0.078)\end{array}$ & $\begin{array}{l}-0.107 \\
(0.084)\end{array}$ \\
\hline \% Muslim & $\begin{array}{l}-0.000 \\
(0.001)\end{array}$ & $\begin{array}{c}0.002 * * \\
(0.001)\end{array}$ & $\begin{array}{l}-0.002 \\
(0.001)\end{array}$ \\
\hline \% Catholic & $\begin{array}{c}-0.003^{* * *} \\
(0.001)\end{array}$ & $\begin{array}{l}-0.001 \\
(0.002)\end{array}$ & $\begin{array}{l}-0.003 \\
(0.002)\end{array}$ \\
\hline$\%$ Protestant & $\begin{array}{c}-0.002 * * * \\
(0.001) \\
\end{array}$ & $\begin{array}{c}-0.004 * * * \\
(0.001) \\
\end{array}$ & $\begin{array}{l}-0.002 * \\
(0.001) \\
\end{array}$ \\
\hline Observations & 34,697 & 35,232 & 37,365 \\
\hline
\end{tabular}

Notes - The dependent variables, listed at the top of rows 1 to 3 , take the value of 1 if the individual agrees or strongly agrees to the statements "Democracy is Bad for the Economy," "Democracies are Indecisive" and "A strong Leader can better manage the country," respectively. The descriptions of the other variables are presented in Table 1 and in the text. The sample consists of individuals from countries with a democracy index less than 7.All regressions include year dummies as well as continent fixed effects. ***, ** and $*$ indicate significance at the $1 \%, 5 \%$ and $10 \%$ levels, respectively. Standard errors are clustered at the country-year level. 
Table 4B

Influence of Joblessness on Perceptions about Performance of Democracy In Democratic Countries (Democracy>=7)

\begin{tabular}{|c|c|c|c|}
\hline & (1) & $(2)$ & (3) \\
\hline & $\begin{array}{l}\text { Democracy is Bad } \\
\text { for the Economy }\end{array}$ & $\begin{array}{l}\text { Democracies } \\
\text { are Indecisive }\end{array}$ & Rogue Leader \\
\hline \multirow[t]{2}{*}{ Jobless } & $0.052 * * *$ & $0.034 * * *$ & $0.064 * * *$ \\
\hline & $(0.010)$ & $(0.011)$ & $(0.011)$ \\
\hline \multirow[t]{2}{*}{ Unemployment Rate } & 0.001 & -0.005 & -0.002 \\
\hline & $(0.004)$ & $(0.004)$ & $(0.003)$ \\
\hline Dislikes Democracy in a & $0.221 * * *$ & $0.133 * * *$ & $0.178 * * *$ \\
\hline Democratic country & $(0.027)$ & $(0.026)$ & $(0.016)$ \\
\hline \multirow[t]{2}{*}{ Female } & $0.025 * * *$ & -0.002 & $-0.017 * * *$ \\
\hline & $(0.005)$ & $(0.006)$ & $(0.005)$ \\
\hline \multirow[t]{2}{*}{ Age } & $-0.009 * * *$ & -0.004 & $-0.006 *$ \\
\hline & $(0.003)$ & $(0.003)$ & $(0.003)$ \\
\hline \multirow[t]{2}{*}{ Medium Income } & $-0.019 * *$ & $-0.017 * *$ & $-0.018 * *$ \\
\hline & $(0.008)$ & $(0.008)$ & $(0.008)$ \\
\hline \multirow[t]{2}{*}{ High Income } & $-0.053 * * *$ & $-0.026 * *$ & $-0.021 *$ \\
\hline & $(0.010)$ & $(0.013)$ & $(0.011)$ \\
\hline \multirow[t]{2}{*}{ Middle Education } & $-0.066 * * *$ & $-0.053 * * *$ & $-0.049 * * *$ \\
\hline & $(0.012)$ & $(0.012)$ & $(0.012)$ \\
\hline \multirow[t]{2}{*}{ High Education } & $-0.154 * * *$ & $-0.146 * * *$ & $-0.119 * * *$ \\
\hline & $(0.015)$ & $(0.014)$ & $(0.014)$ \\
\hline \multirow[t]{2}{*}{ Married } & -0.000 & 0.008 & 0.019* \\
\hline & $(0.011)$ & $(0.008)$ & $(0.010)$ \\
\hline \multirow[t]{2}{*}{ Divorced/Widowed } & 0.007 & $0.026 * * *$ & $0.047 * * *$ \\
\hline & $(0.014)$ & $(0.009)$ & $(0.012)$ \\
\hline \multirow[t]{2}{*}{ Part-time } & 0.010 & 0.007 & 0.011 \\
\hline & $(0.010)$ & $(0.009)$ & $(0.010)$ \\
\hline \multirow[t]{2}{*}{ Self-employed } & 0.002 & 0.003 & -0.003 \\
\hline & $(0.010)$ & $(0.011)$ & $(0.009)$ \\
\hline \multirow[t]{2}{*}{ Retired } & $0.053 * * *$ & $0.059 * * *$ & $0.046 * * *$ \\
\hline & $(0.008)$ & $(0.010)$ & $(0.010)$ \\
\hline \multirow[t]{2}{*}{ Housewife } & 0.000 & -0.004 & $0.036 * * *$ \\
\hline & $(0.011)$ & $(0.011)$ & $(0.012)$ \\
\hline \multirow[t]{2}{*}{ Student } & -0.016 & -0.007 & $-0.020 *$ \\
\hline & $(0.013)$ & $(0.013)$ & $(0.011)$ \\
\hline \multirow[t]{2}{*}{ Other Employed } & -0.000 & 0.012 & $0.031 *$ \\
\hline & (0.019) & $(0.016)$ & $(0.018)$ \\
\hline
\end{tabular}


Table 4B (concluded)

\begin{tabular}{lccc}
\hline & $(1)$ & $(2)$ & $(3)$ \\
\hline 1 Child & $\begin{array}{c}\text { Democracy is Bad } \\
\text { for the Economy }\end{array}$ & $\begin{array}{c}\text { Democracies } \\
\text { are Indecisive }\end{array}$ & Rogue Leader \\
\hline \multirow{3}{*}{ Children } & 0.001 & 0.001 & 0.004 \\
3 Children & $(0.011)$ & $(0.007)$ & $(0.011)$ \\
& 0.014 & 0.012 & -0.009 \\
4+ Children & $(0.010)$ & $(0.008)$ & $(0.009)$ \\
& 0.005 & 0.004 & $-0.018^{*}$ \\
HDI & $(0.012)$ & $(0.010)$ & $(0.010)$ \\
& 0.010 & -0.010 & -0.010 \\
Openness to Trade & $(0.014)$ & $(0.010)$ & $(0.012)$ \\
& $-0.011^{* * *}$ & $-0.010 * * *$ & $-0.012^{* * *}$ \\
Military Expenditure & $(0.003)$ & $(0.003)$ & $(0.004)$ \\
Inflation Rate & -0.000 & -0.001 & 0.001 \\
& $(0.000)$ & $(0.001)$ & $(0.001)$ \\
Country Ever Colonized & 0.024 & 0.004 & 0.023 \\
& $(0.020)$ & $(0.022)$ & $(0.020)$ \\
\% Muslim & 0.013 & 0.011 & $0.026^{* *}$ \\
& $(0.014)$ & $(0.013)$ & $(0.011)$ \\
\% Catholic & 0.009 & -0.106 & -0.021 \\
& $(0.098)$ & $(0.103)$ & $(0.120)$ \\
\% Protestant & $-0.002^{* * *}$ & -0.001 & -0.000 \\
& $(0.001)$ & $(0.001)$ & $(0.001)$ \\
\hline Observations & 0.001 & $0.001 *$ & 0.000 \\
& $(0.001)$ & $(0.001)$ & $(0.001)$ \\
& -0.000 & 0.001 & -0.001 \\
& $(0.001)$ & $(0.001)$ & $(0.001)$ \\
\hline
\end{tabular}

Notes - The dependent variables, listed at the top of rows 1 to 3 , take the value of 1 if the individual agrees or strongly agrees to the statements "Democracy is Bad for the Economy," "Democracies are Indecisive" and "A strong Leader can better manage the country," respectively. The descriptions of the other variables are presented in Table 1 and in the text. The sample consists of individuals from countries with a democracy index greater than or equal to 7 . All regressions include year dummies as well as continent fixed effects. ***, ** and * indicate significance at the $1 \%, 5 \%$ and $10 \%$ levels, respectively. Standard errors are clustered at the country-year level. 
Table 5

Influence of Joblessness on Satisfaction with and Confidence in the Government

Panel A

\begin{tabular}{lccc}
\hline & $(1)$ & $(2)$ & $(3)$ \\
\hline Jobless & $\begin{array}{c}\text { Dissatisfied with } \\
\text { the people in } \\
\text { national office }\end{array}$ & $\begin{array}{c}\text { No Confidence } \\
\text { in government }\end{array}$ & $\begin{array}{c}\text { Country is run } \\
\text { for the Interest } \\
\text { of the few }\end{array}$ \\
Unemployment Rate & 0.010 & -0.014 & -0.019 \\
Democracy is Not Better & $(0.016)$ & $(0.016)$ & $(0.014)$ \\
& $0.009^{* * *}$ & 0.003 & $0.006^{* *}$ \\
\hline Observations & $(0.003)$ & $(0.002)$ & $(0.002)$ \\
\hline
\end{tabular}

Panel B

\begin{tabular}{lccc}
\hline & $(1)$ & $(2)$ & $(3)$ \\
\hline Jobless & $\begin{array}{c}\text { Dissatisfied with } \\
\text { the people in } \\
\text { national office }\end{array}$ & $\begin{array}{c}\text { No Confidence } \\
\text { in government }\end{array}$ & $\begin{array}{c}\text { Country is run } \\
\text { for the Interest } \\
\text { of the few }\end{array}$ \\
Unemployment Rate & 0.011 & -0.015 & -0.019 \\
& $(0.016)$ & $(0.016)$ & $(0.013)$ \\
Dislikes Democracy in a & $0.009^{* * *}$ & 0.003 & $0.006^{* * *}$ \\
Democratic country & $(0.003)$ & $(0.002)$ & $(0.002)$ \\
Likes Democracy in a Less & $0.084^{* * *}$ & $0.087^{* * *}$ & $0.045^{* * *}$ \\
Democratic country & $(0.015)$ & $(0.019)$ & $(0.017)$ \\
\hline Observations & 0.044 & 0.001 & 0.045 \\
\hline
\end{tabular}

Notes - The dependent variables, listed at the top of rows 1 to 3 , take the value of 1 if the individual indicates that he is fairly dissatisfied or very dissatisfied with the way the people now in national office are handling the country's affairs (column 1), if he/she does not have very much confidence or had no confidence in the government (column 2), and if he/she indicates that the country is run by a few big interests rather than the interests of all people (column 3). The descriptions of the other variables are presented in Table 1 and in the text. All regressions include individual level variables, year dummies as well as continent fixed effects as in Table 2. The models in Panel A and B include country characteristics and country fixed effects, respectively. ***, ** and * indicate significance at the $1 \%, 5 \%$ and $10 \%$ levels, respectively. Standard errors are clustered at the country-year level. 
Table 6

Influence of Joblessness Duration on Perceptions about Performance of Democracy

\begin{tabular}{|c|c|c|c|}
\hline & (1) & (2) & (3) \\
\hline & $\begin{array}{l}\text { Democracy is Bad } \\
\text { for the Economy }\end{array}$ & $\begin{array}{l}\text { Democracies are } \\
\text { Indecisive }\end{array}$ & Rogue Leader \\
\hline \multirow[t]{2}{*}{ Jobless: Less than 6 months } & 0.075 & 0.101 & 0.090 \\
\hline & $(0.058)$ & $(0.062)$ & $(0.069)$ \\
\hline \multirow[t]{2}{*}{ Jobless: 6 months to 1 year } & 0.051 & 0.015 & 0.073 \\
\hline & $(0.053)$ & $(0.062)$ & $(0.058)$ \\
\hline \multirow[t]{2}{*}{ Jobless: More than 1 year } & $0.203^{* * *}$ & $0.098 *$ & $0.221 * * *$ \\
\hline & $(0.058)$ & $(0.059)$ & $(0.060)$ \\
\hline \multirow[t]{2}{*}{ Unemployment Rate } & $0.053^{*}$ & 0.041 & 0.011 \\
\hline & $(0.026)$ & $(0.025)$ & $(0.024)$ \\
\hline Dislikes Democracy in a & $0.650 * * *$ & $0.400 * * *$ & $0.513^{* * *}$ \\
\hline Democratic country & $(0.132)$ & $(0.134)$ & $(0.078)$ \\
\hline Likes Democracy in a Less & $-0.753 * * *$ & $-0.935 * * *$ & $-0.503 * *$ \\
\hline Democratic country & $(0.266)$ & $(0.209)$ & $(0.182)$ \\
\hline \multirow[t]{2}{*}{ Female } & $0.117 * * *$ & 0.013 & -0.021 \\
\hline & $(0.020)$ & $(0.025)$ & $(0.023)$ \\
\hline \multirow[t]{2}{*}{ Age } & -0.008 & 0.014 & 0.006 \\
\hline & $(0.012)$ & $(0.011)$ & $(0.012)$ \\
\hline \multirow[t]{2}{*}{ Medium Income } & -0.035 & -0.022 & $-0.057 * * *$ \\
\hline & $(0.026)$ & $(0.032)$ & $(0.022)$ \\
\hline \multirow[t]{2}{*}{ High Income } & $-0.152 * * *$ & $-0.106 * * *$ & $-0.097 * * *$ \\
\hline & $(0.035)$ & $(0.035)$ & $(0.031)$ \\
\hline \multirow[t]{2}{*}{ Middle Education } & $-0.243 * * *$ & $-0.187 * * *$ & $-0.167 * * *$ \\
\hline & $(0.039)$ & $(0.039)$ & $(0.033)$ \\
\hline \multirow[t]{2}{*}{ High Education } & $-0.540 * * *$ & $-0.406 * * *$ & $-0.371 * * *$ \\
\hline & $(0.049)$ & $(0.044)$ & $(0.049)$ \\
\hline \multirow[t]{2}{*}{ Married } & -0.064 & -0.031 & 0.016 \\
\hline & $(0.041)$ & $(0.038)$ & $(0.036)$ \\
\hline \multirow[t]{2}{*}{ Divorced/Widowed } & -0.029 & 0.029 & $0.093 * *$ \\
\hline & $(0.055)$ & $(0.042)$ & $(0.044)$ \\
\hline \multirow[t]{2}{*}{ Part-time } & -0.032 & 0.049 & -0.013 \\
\hline & $(0.041)$ & $(0.040)$ & $(0.048)$ \\
\hline \multirow[t]{2}{*}{ Self-employed } & $-0.108 * *$ & $-0.081^{*}$ & $-0.130 * *$ \\
\hline & $(0.045)$ & $(0.042)$ & $(0.052)$ \\
\hline \multirow[t]{2}{*}{ Retired } & $0.111^{* * *}$ & $0.155^{* * *}$ & $0.072 *$ \\
\hline & $(0.031)$ & $(0.035)$ & $(0.039)$ \\
\hline \multirow[t]{2}{*}{ Housewife } & $-0.129 * *$ & $-0.094^{*}$ & 0.084 \\
\hline & $(0.051)$ & $(0.048)$ & $(0.064)$ \\
\hline
\end{tabular}


Table 6 (concluded)

\begin{tabular}{lccc}
\hline & $(1)$ & $(2)$ & $(3)$ \\
\hline Student & $\begin{array}{c}\text { Democracy is Bad } \\
\text { for the Economy }\end{array}$ & $\begin{array}{c}\text { Democracies are } \\
\text { Indecisive }\end{array}$ & Rogue Leader \\
Other Employed & $-0.121^{* *}$ & $-0.081^{*}$ & $-0.147^{* * *}$ \\
& $(0.046)$ & $(0.046)$ & $(0.041)$ \\
1 Child & 0.069 & -0.026 & 0.054 \\
& $(0.078)$ & $(0.088)$ & $(0.071)$ \\
2 Children & 0.065 & $0.065^{* *}$ & 0.024 \\
& $(0.041)$ & $(0.028)$ & $(0.047)$ \\
3 Children & $0.082^{* *}$ & 0.050 & -0.041 \\
& $(0.040)$ & $(0.039)$ & $(0.041)$ \\
4+ Children & 0.071 & 0.051 & -0.025 \\
& $(0.046)$ & $(0.049)$ & $(0.053)$ \\
HDI & $0.130^{* * *}$ & -0.008 & 0.019 \\
& $(0.048)$ & $(0.062)$ & $(0.050)$ \\
Openness to Trade & -0.008 & -0.007 & -0.023 \\
& $(0.015)$ & $(0.018)$ & $(0.022)$ \\
Military Expenditure & 0.000 & 0.001 & 0.002 \\
& $(0.002)$ & $(0.001)$ & $(0.002)$ \\
Inflation Rate & $0.129^{*}$ & 0.077 & -0.049 \\
& $(0.069)$ & $(0.092)$ & $(0.084)$ \\
\% Muslim & $0.677^{*}$ & $0.735^{*}$ & 0.305 \\
& $(0.347)$ & $(0.430)$ & $(0.295)$ \\
\% Catholic & 0.007 & 0.026 & $0.040^{*}$ \\
& $(0.023)$ & $(0.034)$ & $(0.022)$ \\
\% Protestant & -0.000 & 0.003 & -0.002 \\
& $(0.002)$ & $(0.002)$ & $(0.004)$ \\
\hline Observations & -0.003 & 0.001 & -0.004 \\
No -10.003$)$ & $(0.004)$ \\
\hline
\end{tabular}

Notes - The dependent variables, listed at the top of rows 1 to 3 in each panel, take the value of 1 if the individual agrees or strongly agrees to the statements "Democracy is Bad for the Economy," "Democracies are Indecisive" and "A strong leader can better manage the country," respectively. The descriptions of the other variables are presented in Table 1. The sample used includes individuals from countries to which joblessness duration question is asked. The countries in the sample are Austria, Belarus, Belgium, Bulgaria, Croatia, Czech Republic, Denmark, Estonia, Finland, France, Germany, Greece, Hungary, Ireland, Italy, Latvia, Luxembourg, Netherlands, Poland, Portugal, Romania, Russian Federation, Slovenia, Spain, Turkey, Ukraine and Great Britain. All regressions include year dummies. ${ }^{* * *}$, ** and * indicate significance at the $1 \%, 5 \%$ and $10 \%$ levels, respectively. Standard errors are clustered at the country-year level. 


\section{References}

Acemoglu, Daron and James Robinson. 2001. “A Theory of Political Transitions,” American Economic Review 91(4), pp. 938-63.

Acemoglu, Daron and James Robinson. 2000. "Why Did the West Extend the Franchise? Democracy, Inequality, and Growth in Historical Perspective," Quarterly Journal of Economics 115, pp. 1167-99.

Acemoglu, Daron, Simon Johnson and James A. Robinson. 2001. "The Colonial Origins of Comparative Development: An Empirical Investigation,” American Economic Review 91(5), pp. 1369-1401.

Acemoglu, Daron, Simon Johnson, James Robinson and Pierre Yared. 2008. "Income and Democracy,” American Economic Review 98(3), pp. 808-42.

Acemoglu, Daron, Simon Johnson, James Robinson and Pierre Yared. 2005. "From Education to Democracy?” The American Economic Review 95(2), pp. 44-49.

Barro, Robert. 1999. "Determinants of Democracy,” Journal of Political Economy 107(S6), pp.S158-S183.

Barro, Robert. 1996. “Democracy and Growth,” Journal of Economic Growth 1(1), pp.1-27.

Clark, Andrew. 2003. "Unemployment as a Social Norm: Psychological Evidence from Panel Data,” Journal of Labor Economics 21(2), pp. 323-51.

Clark, Andrew and Andrew Oswald. 1994. “Unhappiness and Unemployment,” Economic Journal 104(May), pp. 648-59.

Dollar, David and Aart Kraay. 2003. “Institutions, Trade, and Growth,” Journal of Monetary Economics 50(1), pp. 133-62.

Eckstein, Harry and Robert Gurr. 1975. "Patterns of Authority: A Structural Basis for Political Inquiry,” New York: John Wiley \& Sons.

Fair, Ray. 1978. "The Effect of Economic Events on Votes for President," Review of Economic and Statistics 60, pp. 159-73. 
Feyrer, James and Bruce Sacerdote. 2009. “Colonialism and Modern Income: Islands as Natural Experiments,” Review of Economics and Statistics 91(2), pp.245-62.

Garand, Games C. and Justin Ulrich. 2009. “The Economy, Subjective Economic Evaluations, and the Presidential Vote.” LSU Department of Political Science Working Paper.

Gasiorowski, Mark. 1995. "Economic Crises and Political Regime Change: An Event History Analysis." American Political Science Review 89(4), pp. 882-97.

Glaeser, Edward, Giacomo Ponzetto andAndrei Shleifer. 2007. "Why does democracy need education?,” Journal of Economic Growth 12, pp.77-99.

Glaeser, Edward, Rafael La Porta, Florencio Lopez-de-Silanes and Andrei Shleifer. 2004. “Do Institutions Cause Growth?,” Journal of Economic Growth 9(3), pp. 271-303. Hadenius, A. and J. Teorell. 2005. “Assessing Alternative Indices of Democracy”, C\&M Working Papers 6, IPSA, August 2005.

Haggard S. and Kaufman R. 1995. “The political economy of democratic transitions,” Princeton, NJ: Princeton University Press.

Hall, Robert and Charles Jones. 1999. "Why Do Some Countries Produce So Much More Output Per Worker Than Others?,” Quarterly Journal of Economics 114(1), pp. 83116.

Heston, Alan, Robert Summers and Bettina Aten. 2006. “Penn World Table Version 6.2”, Center for International Comparisons of Production, Income and Prices at the University of Pennsylvania.

Kramer, Gerald. 1971. "Short-Term Fluctuations in U.S. Voting Behavior, 1896-1964,” American Political Science Review 65, pp.131-43.

La Porta, R., López-de-Silanes, F., Shleifer, A.. and Vishny, R. 1999. “The Quality of Government,” Journal of Law, Economics and Organization 15(1), pp. 222-79.

Lipset, Seymour. 1959. “Some Social Requisites of Democracy: Economic Development and Political Legitimacy,” American Political Science Review 53(1), pp. 69-105. 
Markus, Gregory. 1988. "The Impact of Personal and National Economic Conditions on the Presidential Vote: A Pooled Cross-Sectional Analysis,” American Journal of Political Science 32(1), pp. 137-54.

McCulloch, Robert. 2005. “Income Inequality and the Taste for Revolution,” Journal of Law and Economics 48, pp. 93-123.

Minier , Jenny. 2001. “Is Democracy a Normal Good? Evidence from Democratic Movements,” Southern Economic Journal 67(4), pp. 996-1009.

Mocan, Naci, 2008. “Vengeance,” NBER Working Paper No:14131.

Mulligan, Casep B., Richard Gil and Xavier Sala-i-Martin. 2004. “Do Democracies Have Different Public Policies than Nondemocracies?” Journal of Economic Perspectives 18(1), pp. 51-74.

Nannestad , Peter and Martin Paldam. 1997. "From the Pocketbook of the Welfare Man: A Pooled Cross-Section Study of Economic Voting in Denmark, 1986-92,” British Journal of Political Science 27(1), pp. 119-36.

Papaioannou, Elias and Gregorios Siourounis. 2008. Economic and Social Factors Driving the Third Wave of Democratization,” Journal of Comparative Economics 36(3), pp.365-87.

Prezworski, Adam, Michael Alvarez, Jose Cheibub and Fernando Limongi. 1996. "What Makes Democracy Endure?" Journal of Democracy 7(1), pp. 39-55.

Rigobon , Roberto and Dani Rodrik. 2004. "Rule of Law, Democracy, Openness, and Income: Estimating the Interrelationships,” NBER Working Papers 10750, National Bureau of Economic Research.

Rodrik, Dani. 1999. “Democracies Pay Higher Wages,” Quarterly Journal of Economics 114(3), pp. 707-38.

Stigler, George. 1973. “General Economic Conditions and National Elections,” American Economic Review 63(2), pp. 160-7. 
Teorell, Jan, Nicholas Charron, Marcus Samanni, Sören Holmberg and Bo Rothstein. 2009. The Quality of Government Dataset, version 17June09. University of Gothenburg: The Quality of Government Institute, http://www.qog.pol.gu.se.

Treisman, Daniel. 2000. “The Causes of Corruption:A Cross-National Study,” Journal of Public Economics 76(3), pp.399-457.

Vanhanen, T. 2003b. Democratization and Power Resources 1850-2000 [computer file]. FSD1216, version 1.0 (2003-03-10). Tampere : Finnish Social Science Data Archive [distributor].

Winkelmann, Liliana and Rainer Winkelmann. 1998. "Why Are the Unemployed So Unhappy? Evidence from Panel Data,” Economica 65, pp. 1-15. 